\title{
The absorption of oleic acid in the bile fistula rat
}

\author{
D. R. SAUNDERS ${ }^{1}$ AND A. M. DAWSON \\ From the Medical Unit, Royal Free Hospital, London
}

EDITORIAL SYNOPSIS A technique is described for collecting thoracic duct lymph in a portable glass saddle from an unrestrained rat.

Uniformly labelled oleic acid in various physical states was given to rats with thoracic duct and bile fistulae to study the influence of bile salts on the amount absorbed and on the route of transport and esterification after absorption. It is suggested that in addition to their emulsifying action bile salts may stimulate the esterification of absorbed oleic acid by the intestinal mucosa.

When long-chain fatty acids are absorbed, they are esterified by the small intestinal mucosal cell to form triglycerides before being discharged into the lymph as chylomicrons (Bloom, Chaikoff, Reinhardt, Entenman, and Dauben, 1950; Borgström, 1952b), while short-chain, water-soluble fatty acids pass through the mucosal cell into the portal vein (Hughes and Wimmer, 1935) as the free acids (Borgström, 1955).

Although moderate amounts of fat are well absorbed in animals with bile fistulae (Munk, 1890; Pessoa, Kim, and Ivy, 1953), Borgström (1953) demonstrated an abnormal route of transport of absorbed long-chain fatty acids, for, after feeding $\left[1-{ }^{14} \mathrm{C}\right]$ palmitic acid in corn oil to rats with bile fistulae, less than one quarter of the absorbed radioactivity was recovered in the intestinal lymph. Borgström suggested that bile salts may affect fat absorption not only by their action in the gut lumen but by directly affecting the metabolism of the small intestinal mucosal cell. This idea has been supported by experiments in vitro which suggest that conjugated bile salts stimulate the esterification of long-chain fatty acids by the mucosal cell (Dawson and lsselbacher, 1960).

In the present experiments $\left[{ }^{14} \mathrm{C}\right]$ oleic acid was given in various physical states to rats with thoracic duct and bile fistulae in an attempt to clarify the importance of bile salts, both in the esterification of fatty acids by the small intestinal mucosa, and the subsequent route of transport after absorption. The free acid was given, without triglyceride, so that transesterification in the small intestinal lumen would not lead to ambiguity of the chemical form in which the fat was absorbed.

${ }^{1}$ R. Samuel McLaughlin travelling fellow. Present address: Department of Medicine, Royal Victoria Hospital, Montreal, Canada.

\section{METHODS AMD MATERIALS}

Uniformly (U) labelled $\left[{ }^{14} \mathrm{C}\right]$ oleic acid was purchased from the Radiochemical Centre, Amersham, Bucks, and this material was diluted with oleic acid, B.P.

Sodium taurocholate, prepared according to Norman (1955), contained less than $5 \%$ of free cholic acid.

Emulsions of $\left[\mathrm{U}^{14} \mathrm{C}\right]$ oleic acid in either polyoxyethylene sorbitan monolaurate (Tween 20) or sodium taurocholate were made by first dissolving the fatty acid in I $\mathrm{N} \mathrm{NaOH}$, adding the emulsifying agent, adjusting the $p \mathrm{H}$ to 7.0 with $\mathrm{HCl}$, and finally making up to volume so that the composition was (mg./ml.):[U- $\left.{ }^{14} \mathrm{C}\right]$ oleic acid, 20, with either Tween 20,50 , or sodium taurocholate, 10. The optical density of the Tween emulsion was 0.360 (read at $650 \mathrm{~m} \mu$ in a Zeiss spectrophotometer, PQII, against $0 \cdot 1 \quad \mathrm{M} \mathrm{Na}_{2} \mathrm{HPO}_{4}$ ) and that of the taurocholate emulsion was 0.450 .

An emulsion of $\left[\mathrm{U}-{ }^{14} \mathrm{C}\right]$ oleic acid in $0.1 \mathrm{M} \mathrm{Na}_{2} \mathrm{HPO}_{4}$ was prepared by emulsifying in an ultrasonic disintegrator $^{2}$ for one hour. The $p \mathrm{H}$ was adjusted to 7.4 with $\mathrm{HCl}$ and the final composition of $\left[\mathrm{U}-{ }^{14} \mathrm{C}\right]$ oleic acid was $8 \mathrm{mg}$. $/ \mathrm{ml}$. The optical density was 1.090 .

Radioactive materials were counted in an Ecko liquidscintillation counter. The liquid scintillator consisted of (g./100 ml.):2,5-diphenyloxazole, $0 \cdot 3$, and p-bis-2-(5phenyloxazolyl)-benzene ${ }^{3}, 0.01$ in xylene. $\left[1{ }^{14} \mathrm{C}\right]$ hexadecane was used as a reference material to determine the phosphorescence quenching of individual samples and so that the radioactivity could be expressed as disintegrations per minute. The efficiency of the counting system was $45 \%$; background 12 counts/minute.

\section{EXPERIMENTS WITH THORACIC DUCT FISTULAE}

Female white rats, weighing 200 to 250 g., were starved for $24 \mathrm{hr}$. before operating. Under ether anaesthesia the thoracic duct was cannulated (Bollman, Cain, and

${ }^{2}$ Measuring and Scientific Equipment Ltd., London.

${ }^{3}$ Nuclear Enterprises, Edinburgh. 
Grindlay, 1948) with polyethylene tubing $40.5 \mathrm{~mm}$ internal diameter, which had been previously shaped to follow the diaphragmatic contour by heating in water at $90^{\circ}$. The cannula was brought through the muscles of the anterior abdominal wall, and threaded under the skin to emerge between the shoulder blades. A glass saddle, larger than that described by Van Zyl (1957), consisted of two paniers (each of $17.5 \mathrm{ml}$. capacity) connected by a Y-shaped piece of glass tubing, internal diameter $0.5 \mathrm{~cm}$., and was fixed in place with steel wire skin sutures. The free end of the thoracic duct cannula was inserted into one of the paniers of the glass saddle. When needed polythene tubing was also used to fashion a duodenostomy and cannulate the bile duct. On such occasions these polythene tubes were brought out of the abdomen and under the skin along with the thoracic duct cannula. The bile duct cannula was splintered behind one of the paniers of the glass saddle and allowed to drain freely. Thereafter the animal was placed in an ordinary cage without restraint and allowed to drink ad lib. a solution of (g./100 ml.) glucose, $5 ; \mathrm{NaCl}, 0.5 ; \mathrm{KCl}, 0.04$. The day following operation the rats were given $\left[\mathrm{U}-{ }^{14} \mathrm{C}\right]$ oleic acid by stomach tube in early experiments, but later by duodenostomy, Two doses were used: $80 \cdot 0 \mathrm{mg}$. of $\left[\mathrm{U}-{ }^{14} \mathrm{C}\right]$ oleic acid was given as the oil (vol. $0 \cdot 1 \mathrm{ml}$. delivered by a $0.5 \mathrm{ml}$. tuberculin syringe), or as an emulsion in Tween 20 , or taurocholate $(1.0 \mathrm{ml}$. of emulsion every $15 \mathrm{~min}$. for four doses); $8.0 \mathrm{mg}$. of $\left[\mathrm{U}-{ }^{14} \mathrm{C}\right]$ oleic acid was given as the oil (vol. $0.01 \mathrm{ml}$. delivered by a microlitre syringe $\mathrm{e}^{5}$, or as an emulsion in taurocholate (vol., $1.0 \mathrm{ml}$.). The duodenostomy tube was flushed through with $1 \mathrm{ml}$. of $0.15 \mathrm{M} \mathrm{NaCl}$. The thoracic duct lymph was collected for the next 12 hours and was prevented from clotting by a drop of heparin in the glass saddle, after which the rats were killed under ether anaesthesia. Animals were excluded if abnormalities such as dilated intestinal lymphatics, dilated bile ducts, or hyperaemic intestine were found at necropsy. Animals were also excluded if the collected lymph was grossly blood-tinged, of if the volume was less than $2 \mathrm{ml}$./hour. The entire gastrointestinal tract was removed, and together with the faeces was saponified for two hours in $50 \mathrm{ml}$. of equal volumes of ethanol and $\mathrm{KOH}, 30 \mathrm{~g} . / 100 \mathrm{ml}$. After acidifying, fatty acids were extracted with light petroleum (b.p. 60 to $80^{\circ} \mathrm{C}$.), and from the radioactivity in this fraction the amount of unabsorbed [U-14 $\mathrm{C}$ ] oleic acid was determined. As it was found that only 2 or $3 \%$ of the administered ${ }^{14} \mathrm{C}$ was in the intestinal wall in control and bile fistula rats, separate analyses of intestinal wall and lumenal contents were not done routinely.

Lymph from each rat was made up to volume and a portion taken for extraction of lipid. To the chilled $\left(10^{\circ} \mathrm{C}\right.$.) portion of lymph, trichloroacetic acid was added so that the final concentration was $5 \mathrm{~g} . / 100 \mathrm{ml}$. After centrifuging (2,500 r.p.m. for $15 \mathrm{~min}$. at $4^{\circ} \mathrm{C}$.), lipid was extracted from the precipitate by 20 vol. of $\mathrm{CHCl}_{3}$ methanol (2:1) (Folch, Lees, and Sloane Stanley, 1957). $\mathrm{CaCl}_{2}, 0.04 \mathrm{~g} . / 100 \mathrm{ml}$. (one-fifth of the volume of $\mathrm{CHCl}_{3}$ methanol), was added, the mixture shaken and separated into two phases of centrifuging (2,500 r.p.m. for $5 \mathrm{~min}$.).

•Allen and Hanbury Ltd., London.

'The Hamilton Co., Whittier, California.
A portion of the $\mathrm{CHCl}_{3}$ phase was evaporated to dryness at $35^{\circ} \mathrm{C}$. in an atmosphere of $\mathrm{N}_{2}$ and made up to volume with light petroleum (b.p. 60 to $80^{\circ} \mathrm{C}$.). From the amount of radioactivity in a sample of the light petroleum the radioactivity in lymph lipids was calculated, and this value was expressed as the percentage of absorbed radioactivity recovered in lymph lipids.

In about three quarters of the experiments a sample of lymph lipids in light petroleum was placed on a chromatography column ${ }^{6}(1 \mathrm{~cm}$. diameter) with silicic acid $(1 \mathrm{~g}$.) and $0.5 \mathrm{~g}$. of Hyflow Supercel? ${ }^{2}$ Lipids, other than phospholipids, were eluted with $50 \mathrm{ml}$. of diethyl ether, evaporated to dryness, and made up to volume with light petroleum (b.p. 60 to $80^{\circ} \mathrm{C}$.). The light petroleum was washed with a mixture of equal volumes of ethanol and $0.5 \mathrm{~N} \mathrm{NaOH}$ (Borgström, 1952a) by passing three lower phases through two upper phases and centrifuging to ensure separation of phases. The free fatty acids were extracted from the combined lower phases with light petroleum (b.p. 60 to $80^{\circ} \mathrm{C}$.) after acidifying. After assaying the radioactivity of the upper phase (neutral fats) the results were expressed as the percentage of the lipid radioactivity as free fatty acid. Preliminary experiments showed that the radioactivity in the phospholipid fraction, obtained from control and bile fistula rats given oleic acid either as the oil or an emulsion, never exceeded $3 \%$ of the lymph lipid radioactivity, and was therefore omitted from the calculation. The adequacy of the separation of free fatty acids from the neutral fat fraction was checked by thin-layer silicic acid chromatography (Mangold and Malins, 1960). The chromatograms were run by ascending technique for two hours at room temperature using diethyl ether, light petroleum (b.p. 60 to $80^{\circ} \mathrm{C}$.), and acetic acid (1.0: 9.0:0.1, by vol.). $I_{2}$ vapour was used for locating unsaturated substances. The $\mathrm{Rf}$ value of material extracted by light petroleum from the lower phase was identical with that of an authentic sample of oleic acid. No such spot was detected in samples from the upper phase.

\section{EXPERIMENTS ON RADIOACTIVITY IN PORTAL BLOOD}

Under ether anaesthesia, simultaneous samples of blood were taken from the portal vein and abdominal aorta a half to two hours after giving $\left[\mathrm{U}-{ }^{14} \mathrm{C}\right]$ oleic acid $(80 \cdot 0 \mathrm{mg}$.: $2 \cdot 0 \mu \mathrm{c}$.) by duodenostomy. The preceding day a bile fistula and duodenostomy had been performed in one group of rats, and a duodenostomy only in the control group. Lipid was extracted from the blood samples with 20 vol. of $\mathrm{CHCl}_{3}$-methanol (2:1) and the blood lipids separated into free fatty acids and neutral fat fractions after initial separation of phospholipids.

$$
\begin{aligned}
& \text { RESULTS OF EXPERIMENTS WITH } 80.0 \mathrm{MG} \text {. } \\
& \text { [U-14 } \mathrm{C} \text { ] OLEIC ACID }
\end{aligned}
$$

CONTROL RATS When [U- $\left.{ }^{14} \mathrm{C}\right]$ oleic acid $(80.0 \mathrm{mg}$; $0.22 \mu \mathrm{C}$ ) was fed to control rats (Table 1 ) a mean of $46.7 \mathrm{ml}$. of lymph was produced in 12 hours, $72.0 \%$ of the radioactivity was absorbed, and of the amount

'Mallinckroft Chemical Works; 100 mesh.

${ }^{7}$ Hopkin and Williams Ltd.. 
TABLE I

RECOVERY OF RADIOACTIVITY IN CONTROL RATS 12 HOURS AFTER GIVING [U-14 C]

OLEIC ACID $(80 \mathrm{mg}$.) AS THE OIL BY STOMACH TUBE (GROUP A), AS THE OIL BY DUODENOSTOMY (GROUP B), OR AS AN EMULSION IN TWEEN 20 BY DUODENOSTOMY (GROUP C)

\begin{tabular}{|c|c|c|c|c|}
\hline Group & Lymph (ml.) & $\begin{array}{l}{ }^{14} C \text { Absorbed } \\
(\%)\end{array}$ & $\begin{array}{l}\text { Absorbed }{ }^{14} C \text { Recovered } \\
\text { in Lymph Lipids (\%) }\end{array}$ & $\begin{array}{l}\text { Lymph Lipid }{ }^{14} C \text { as Free } \\
\text { Fatty Acid }(\%)\end{array}$ \\
\hline $\mathbf{A}$ & $\begin{array}{r}25 \\
36 \\
50 \\
111\end{array}$ & $\begin{array}{l}59 \cdot 0 \\
89 \cdot 0 \\
60 \cdot 0 \\
76 \cdot 0\end{array}$ & $\begin{array}{l}86 \cdot 0 \\
98 \cdot 0 \\
67 \cdot 0 \\
90 \cdot 0\end{array}$ & \} \\
\hline B & $\begin{array}{l}60 \\
50 \\
40\end{array}$ & $\begin{array}{l}91.0 \\
72.0 \\
45.0\end{array}$ & $\begin{array}{l}84.0 \\
60.0 \\
97.0\end{array}$ & $\begin{array}{l}3 \cdot 3 \\
4 \cdot 4 \\
9 \cdot 0\end{array}$ \\
\hline $\begin{array}{c}\text { C } \\
\text { Mean } \pm \text { S.E.M. }{ }^{2}\end{array}$ & $\begin{array}{l}30 \\
40 \\
25 \\
46 \cdot 7 \pm 8 \cdot 0\end{array}$ & $\begin{array}{l}62 \cdot 0 \\
91 \cdot 0 \\
75 \cdot 0 \\
72 \cdot 0 \pm 5 \cdot 0\end{array}$ & $\begin{array}{l}71 \cdot 0 \\
81 \cdot 0 \\
87 \cdot 0 \\
82 \cdot 1 \pm 4 \cdot 0\end{array}$ & $\begin{array}{l}3 \cdot 4 \\
6 \cdot 2 \\
7 \cdot 1 \\
5 \cdot 6 \pm 0.9\end{array}$ \\
\hline
\end{tabular}

${ }^{1}$ Pooled sample from group $\mathbf{A}$.

${ }^{2}$ In calculating the mean \pm S.E.M. it was assumed that the values in groups $A, B$, and $C$ were from a homogeneous population, as the difference between groups of measurements was not significant $(\mathrm{P}<1 \cdot 0)$ by analysis of variance (Mainland, 1952). The mean percent lipid ${ }^{10} \mathrm{C}$ as free fatty acid was calculated from the values in groups $B$ and $C$.

absorbed $82 \cdot 1 \%$ was recovered in lymph lipids. Almost all of the lymph lipid radioactivity was in the neutral fat fraction; only $5.6 \%$ was free fatty acid. There was no difference if the fat were given by duodenostomy rather than stomach tube, or if it were given as an emulsion in Tween 20 instead of as the oil.

BILE Fistula RATS When [U-14 $\mathrm{C}$ ] oleic acid $(80 \cdot 0$ mg.; $0.22 \mu \mathrm{C}$ ) was given as an oil to rats with bile fistulae, there was no significant difference in lymph production when compared with controls (P>0.1); $49.1 \%$ of the administered ${ }^{14} \mathrm{C}$ was absorbed, significantly less than in the control group $(P<0.01)$. The striking difference from the control group was that only $7 \cdot 2 \%$ of the ${ }^{14} \mathrm{C}$ absorbed was recovered in lymph lipids, and of this amount $28.0 \%$ was free fatty acid. These results suggest that in the absence of bile not only was there an altered route of transport of absorbed oleic acid but there was some failure in esterification of the fatty acid. Further evidence for transport by the portal vein was that the percentage of absorbed radioactivity recovered in the livers of the bile fistula rats was much higher than in the control group (4.7 to $19 \cdot 2$ compared with 0.00 to 0.64 ), while after giving $\left[\mathrm{U}-{ }^{14} \mathrm{C}\right.$ ] oleic acid $(80.0 \mathrm{mg}$; $2.0 \mu \mathrm{C}$.) the ratio of ${ }^{14} \mathrm{C} / \mathrm{ml}$. of portal blood to aortic blood was 0.97 to 1.17 in the controls compared with 1.24 to 15.00 in the bile fistula rats (Table III). The other significant fact is that the percentage of the portal blood radioactivity as free fatty acid was higher in the bile fistula group. This suggests that not only is the absorbed oleic acid transported in the portal blood in the bile fistula rat but this has not been esterified by the intestinal mucosa.
TABLE III

RECOVERY OF RADIOACTIVITY IN SIMULTANEOUSLY DRAWN SAMPLES FROM PORTAL VEIN AND ABDOMINAL AORTA AFTER GIVING [U- ${ }^{14} \mathrm{C}$ ] OLEIC ACID BY DUODENOSTOMY

\begin{tabular}{lcc} 
Experiment & $\begin{array}{l}{ }^{14} C \text { Portal } \\
\text { Control }\end{array}$ & $\begin{array}{c}\text { Portal Blood "CC as } \\
\text { Fatty Acid \%) }\end{array}$ \\
\hline & 1.14 & 16.9 \\
& 1.17 & 38.2 \\
& 1.09 & 29.2 \\
Mean + 2 S.D & 1.01 & $9 \cdot 1$ \\
Bile fistula & 0.97 & 13.0 \\
& $1.08+0.17$ & $21.3+24.2$ \\
& 1.70 & 95.5 \\
& 1.26 & 78.7 \\
& 2.64 & 76.4 \\
& 1.24 & 76.2 \\
& 15.00 & 91.6
\end{tabular}

When $\left[\mathrm{U}-{ }^{14} \mathrm{C}\right]$ oleic acid $(80.0 \mathrm{mg} . ; 0.22 \mu \mathrm{C}$.) emulsified in either Tween 20 or taurocholate was given to bile fistula rats, although the amount absorbed was not markedly increased, the route of transport was altered (Table IV). Compared with experiments in which oleic acid was given as the oil to bile fistula rats (Table $\mathrm{II}$ ), $57.6 \%$ was absorbed in the Tween experiments $(P>0.1)$, and $66.5 \%$ in the taurocholate experiments $(0.05>P>0.01)$; of the radioactivity absorbed, $44.5 \%$ was recovered in lymph lipids in the Tween experiments and 50.7\% in the taurocholate experiments. When the results of the Tween and taurocholate experiments were compared, there was no significant difference in the amount absorbed $(P>0.1)$ or in the recovery of ${ }^{14} \mathrm{C}$ in lymph lipids $(P>0 \cdot 1)$. In the Tween experiments the proportion of lymph lipid ${ }^{14} \mathrm{C}$ as free fatty acids was high and the same as when oleic acid was given as the oil to bile fistula rats $(P>0 \cdot 1)$. On the other 
TABLE II

RECOVERY OF RADIOACTIVITY IN BILE FISTULA RATS 12 HOURS AFTER GIVING [U-14 C] OLEIC ACID (80 mg.) AS THE OIL BY STOMACH TUBE (GROUP A) OR BY DUODENOSTOMY (GROUP B)

\begin{tabular}{|c|c|c|c|c|}
\hline Group & $\operatorname{Lymph}(m l)$. & $\begin{array}{l}{ }^{14} C \text { Absorbed } \\
(\%)\end{array}$ & $\begin{array}{l}\text { Absorbed }{ }^{14} C \text { Recovered } \\
\text { in Lymph Lipids }(\%)\end{array}$ & $\begin{array}{l}\text { Lymph Lipid }{ }^{14} C \text { as Free } \\
\text { Fatty Acid }(\%)\end{array}$ \\
\hline $\mathbf{A}$ & $\begin{array}{l}25 \\
75 \\
50 \\
93\end{array}$ & $\begin{array}{l}33.0 \\
54 \cdot 0 \\
60.2 \\
43.0\end{array}$ & $\begin{array}{r}4 \cdot 8 \\
4 \cdot 5 \\
12 \cdot 3 \\
6.4\end{array}$ & \} \\
\hline B & $\begin{array}{l}70 \\
25 \\
35 \\
24 \\
70\end{array}$ & $\begin{array}{l}40 \cdot 0 \\
34 \cdot 0 \\
45 \cdot 6 \\
67 \cdot 7 \\
64 \cdot 5\end{array}$ & $\begin{array}{l}5.9 \\
8 \cdot 3 \\
9 \cdot 6 \\
8 \cdot 9 \\
4 \cdot 1\end{array}$ & $\begin{array}{l}24 \cdot 9 \\
25 \cdot 3 \\
31 \cdot 5 \\
20 \cdot 7 \\
37 \cdot 6\end{array}$ \\
\hline Mean \pm S.E.M. ${ }^{2}$ & $52 \pm 9$ & $49 \cdot 1 \pm 4 \cdot 7$ & $7 \cdot 2 \pm 0.9$ & $28.0 \pm 3.0$ \\
\hline
\end{tabular}

'Pooled lymph from group $A$

'In calculating the mean \pm S.E.M. it was assumed that the values in groups $\mathbf{A}$ and $\mathbf{B}$ were from a homogeneous population, as the difference between the means of measurements in $A$ and $B$ was not significant $(P>0 \cdot 1)$. The mean percent lipid ${ }^{14} \mathrm{C}$ as free fatty acid was calculated from the values in group $B$.

\section{TABLE IV}

RECOVERY OF RADIOACTIVITY AFTER GIVING [U-14 C] OLEIC ACID (80 mg.) BY DUODENOSTOMY TO BILE FISTULA RATS ${ }^{1}$

\begin{tabular}{lccc} 
Oleic Acid Emulsion & ${ }^{14} C$ Absorbed (\%) & $\begin{array}{l}\text { Absorbed }{ }^{14} C \text { Recovered in } \\
\text { Lymph Lipids (\%) }\end{array}$ & $\begin{array}{l}\text { Lymph Lipid }{ }^{14} \text { C as Free Fatty Acid } \\
(\%)\end{array}$ \\
\hline Tween 20 & $57.6 \pm 2 \cdot 5(6)$ & $44.5 \pm 5 \cdot 1(6)$ & $22.3 \pm 2.6(6)$ \\
Taurocholate & $66.5 \pm 6.1(10)$ & $50.7 \pm 3.7(10)$ & $9.0 \pm 1 \cdot 2(7)$
\end{tabular}

${ }^{1}$ The results are expressed as the mean \pm S.E.M. with the number of observations in parentheses.

hand, there was a highly significant reduction towards normal in the free fatty acid fraction when the emulsifying agent was taurocholate rather than Tween $20(\mathrm{P}<0.01)$.

\section{RESULTS OF EXPERIMENTS WITH 8.0 MG. $\left[\mathrm{U}^{14} \mathrm{C}\right]$ OLEIC ACID}

It was desirable to test the absorption of an oleic acid emulsion prepared without the addition of an emulsifying agent which might alter the metabolism of the small intestinal mucosa. Such an emulsion was prepared in an ultrasonic disintegrator, but the maximum concentration of oleic acid obtainable by this method was $8.0 \mathrm{mg} . / \mathrm{ml}$. Therefore, it was necessary to have series of rats with and without bile fistulae given oleic acid, $8.0 \mathrm{mg}$., for comparison. The results are shown in Table V.

CONTROL RATS The mean values for the percentage of ${ }^{14} \mathrm{C}$ absorbed, the percentage of absorbed ${ }^{14} \mathrm{C}$ recovered in lymph lipids, and the percentage of lymph lipid ${ }^{14} \mathrm{C}$ as free fatty acid were $87 \cdot 1,63 \cdot 2$, and 1.8 respectively. When these figures are compared with controls given $80.0 \mathrm{mg}$. of $\left[\mathrm{U}-{ }^{14} \mathrm{C}\right]$ oleic acid (Table I), the percentage absorbed was higher $(0.05>P>0.01)$, the percentage of absorbed ${ }^{14} \mathrm{C}$ in lymph lipids was less $(P<0.01)$, and less of the lymph lipid ${ }^{14} \mathrm{C}$ was free fatty acid $(\mathrm{P}<0 \cdot 01)$.

BILE FISTULA RATS When [U-14 $\mathrm{C}$ ] oleic acid $(8 \cdot 0 \mathrm{mg}$; $0.22 \mu \mathrm{C}$.) was given as the oil to the bile fistula rats,

\section{TABLE V}

RECOVERY OF RADIOACTIVITY AFTER GIVING [U- ${ }^{14} \mathrm{C}$ ] OLEIC ACID (80 $\mathrm{mg}$.) BY DUODENOSTOMY AS THE OIL, AS A MECHANICALLY PREPARED EMULSION (SONICATED), OR AS AN EMULSION IN TAUROCHOLATE

\begin{tabular}{|c|c|c|c|c|}
\hline Experiment & $\begin{array}{l}\text { Form of Oleic Acid } \\
\text { Given }\end{array}$ & ${ }^{14} \mathrm{C}$ Absorbed (\%) & $\begin{array}{l}\text { Absorbed }{ }^{14} C \text { Recovered } \\
\text { in Lymph Lipids }(\%)\end{array}$ & $\begin{array}{l}\text { Lymph Lipid }{ }^{14} C \text { as Free } \\
\text { Acid }(\%)\end{array}$ \\
\hline $\begin{array}{l}\text { Control } \\
\text { Bile fistula } \\
\text { Bile fistula } \\
\text { Bile fistula }\end{array}$ & $\begin{array}{l}\text { Oil } \\
\text { Oil } \\
\text { Sonicated emulsion } \\
\text { Taurocholate emulsion }\end{array}$ & $\begin{array}{l}87 \cdot 1 \pm 3 \cdot 6(7) \\
48 \cdot 1 \pm 5 \cdot 2(5) \\
46 \cdot 7 \pm 3 \cdot 9(4) \\
65 \cdot 6 \pm 2 \cdot 6(4)\end{array}$ & $\begin{array}{l}63 \cdot 2 \pm 2 \cdot 5(7) \\
13 \cdot 9 \pm 1 \cdot 4(5) \\
72 \cdot 7 \pm 8 \cdot 5(4) \\
82 \cdot 5 \pm 4 \cdot 1(4)\end{array}$ & $\begin{aligned} 1.8 & \pm 0.02(7) \\
24 \cdot 6 & \pm 3 \cdot 5(5) \\
23.3 & \pm 4 \cdot 6(4) \\
1.9 & \pm 0.12(4)\end{aligned}$ \\
\hline
\end{tabular}

${ }^{1}$ The results are expressed as the mean \pm S.E.M. with the number of observations in parentheses. 
$48.1 \%$ was absorbed, $13.9 \%$ of the absorbed ${ }^{14} \mathrm{C}$ was recovered in lymph lipids, and $24.6 \%$ of the lymph lipid ${ }^{14} \mathrm{C}$ was free fatty acid. Comparing these results with the controls given $8.0 \mathrm{mg}$. of oleic acid, less was absorbed $(P<0.01)$; there was an altered route of transport of the ${ }^{14} \mathrm{C}$ absorbed, and the percentage of lymph lipid ${ }^{14} \mathrm{C}$ as free fatty acid was much higher in the bile fistula group, but did not differ significantly from that obtained when $80.0 \mathrm{mg}$. of $\left[\mathrm{U}-{ }^{14} \mathrm{C}\right]$ oleic acid was given $(\mathrm{P}>0 \cdot 1)$.

When $\left[\mathrm{U}-{ }^{14} \mathrm{C}\right]$ oleic acid $(8.0 \mathrm{mg} . ; 0.22 \mu \mathrm{c}$.) was given as a mechanically prepared (sonicated) emulsion to bile fistula rats, and the results compared with those in the bile fistula group given the oil, there was no difference in either the ${ }^{14} \mathrm{C}$ absorbed $(P>0.1)$, or in the proportion of lymph lipid ${ }^{14} \mathrm{C}$ as free fatty acid $(\mathrm{P}>0 \cdot 1)$. However, $72 \cdot 7 \%$ of the ${ }^{14} \mathrm{C}$ absorbed was recovered in lymph lipids, clear evidence that the route of transport had been altered by emulsifying the oleic acid.

The absorption of $\left[\mathrm{U}-{ }^{14} \mathrm{C}\right]$ oleic acid $(8.0 \mathrm{mg}$; $0.22 \mu \mathrm{c}$.) given emulsified in taurocholate to bile fistula animals was higher than in the experiments with the sonicated emulsion $(\mathrm{P}<0.01)$ but there was no difference in the percentage of the absorbed ${ }^{14} \mathrm{C}$ recovered in lymph lipids $(P>0 \cdot 1)$. The striking difference in these two groups is that the percentage of lymph lipid ${ }^{14} \mathrm{C}$ as free fatty acid was similar to the controls following the taurocholate but not the sonicated emulsion.

\section{DISCUSSION}

The use of a portable glass saddle for collecting thoracic duct lymph avoids the need for restraining the rat with its attendant physiological disadvantages. The volumes of lymph obtained by this technique are similar to those of Borgström and Tryding (1956) and Vahouny, Woo, and Treadwell (1958), and are probably maximal for rats drinking saline solutions ad lib.

Although in the control rats given $\left[\mathrm{U}^{14} \mathrm{C}\right]$ oleic acid (80.0 mg.) only $72.0 \%$ of the radioactivity was absorbed in 12 hours, this is similar to a mean absorption of $78.2 \%$ in the 24 hours after giving $\left[1-{ }^{14} \mathrm{C}\right]$ oleic acid to rats (Bergström, Blomstrand, and Borgström, 1954). Possibly the surgical procedures diminish the capacity of the small intestine to absorb fat.

The experiments on bile fistula rats confirm the observations that in the absence of bile fat absorption is only slightly impaired (Munk, 1890; Pessoa et al., 1953). The low recovery of absorbed radioactivity in the thoracic duct lymph is similar to that reported by Borgström (1953), and presumably most of the absorbed fatty acid was transported by the portal vein. This assumption is supported by finding a greater concentration of radioactivity in the portal vein than in the aorta after feeding $\left[\mathrm{U}-{ }^{14} \mathrm{C}\right]$ oleic acid to bile fistula rats; the wide scatter of results in this experiment is probably due to differences in the rate of fat absorption at the time of sampling, but four of the five values were higher than the mean +2 S.D. of a control group. In addition there was an impaired esterification of absorbed fatty acid by the intestinal mucosa in the absence of bile as the portal blood lipid radioactivity was predominantly free fatty acid, and there was an abnormally high proportion $(28.0 \%)$ of the lymph lipid radioactivity in the free fatty acid fraction. In the control rats the absorbed fat was mainly esterified which is consistent with the range of 3.8 to $11.8 \%$ of lymph lipid as free fatty acid reported by Borgström and Tryding (1956). Normally, most of the lymph free fatty acid seems to be of endogenous origin (Blomstrand and Dahlbäck, 1960).

As the importance of bile in fat absorption is thought to be due to the emulsifying properties of conjugated bile salts in the small intestinal lumen, attempts were made to correct the defects of aborption in bile fistula rats by giving the oleic acid emulsified in taurocholate, the predominant bile salt in rat bile (Haslewood, 1955), in Tween 20, or in an ultrasonic disintegrator without added emulsifying agents. These emulsions were given intraduodenally to prevent their disruption by gastric acidity. The amount absorbed was slightly increased by taurocholate, but the route of transport, with appearance of fat in the lymph, was equally well corrected by all three. Thus, in some way the size of the absorbed fat particles determines the subsequent route of transport. Yet, neither the Tween 20 nor sonicated emulsions corrected the defect in esterification as shown by the constant high percentage of absorbed oleic acid in the free fatty acid fraction of the lymph lipids. It is unlikely that Tween 20 inhibited esterification, for when given to control rats there was no difference from those controls given the oleic acid as the oil. The criticism that the esterification defect is illusory, that although the proportion of unesterified fat is abnormally high, the absolute amount transported as free fatty acid is the same in control and bile fistula rats given the oil can be met by the results of the experiments where oleic acid was given as an emulsion. Here, after giving the Tween 20 or sonicated emulsions there was a significantly higher amount of fat transported as free fatty acid in the lymph as compared with controls. On the other hand, taurocholate in a concentration similar to that which has been found in the intestinal lumen (Borgström, Dahlqvist, Lundh, and Sjövall, 1957) partially corrected the esterification defect. This supports evidence in vitro 
that taurocholate can directly affect the esterification of long-chain fatty acids by the mucosal cell (Dawson and Isselbacher, 1960). An alternative, less likely, explanation would be that the size of the fatty acid particle determines whether or not it is esterified, and that this critical size is only obtained by taurocholate and not the other two emulsions. Further evidence that bile salts might affect mucosal metabolism is given by Olson (1961) who reported that the conversion of $\beta$-carotene to vitamin $A$ by rat small gut mucosa in vivo occurs only when the $\beta$ carotene is emulsified in bile salts, and not other agents such as Tween 80 . Recent evidence that bile salts are mainly absorbed in the ileum (Baker and Searle, 1960; Weiner and Lack, 1962) suggests that any cellular action of bile salts might be mediated by an action on the cell membrane, possibly analogous to an action of insulin-stimulating pinocytosis by adipose tissue cells (Barrnett and Ball, 1959). Some fat is absorbed by pinocytosis (Palay and Karlin, 1959) and the membrane which surrounds the fat globule is a part of the endoplasmic reticulum of the cell which contains most of the enzymes necessary for triglyceride synthesis (Hübscher, Clark, and Webb, 1962; Senior and Isselbacher, 1961). Thus it is possible that fatty acids entering the cell by pinocytosis are converted to triglyceride while those entering in another manner remain unesterified.

The transport of absorbed long-chain fatty acids in the portal blood of bile fistula rats is reminiscent of the original partition theory (Frazer, 1943) in which it was claimed that any free fatty acid formed in the intestinal lumen was mainly absorbed as a water-soluble soap and passed through into the portal vein, while lower glycerides and bile salts emulsified the rest of the fat which passed into the lymph. This theory was modified with the introduction of ${ }^{14} \mathrm{C}$ labelled fatty acids when it was shown that no matter the form of the fat fed-free acid or triglyceride-the extent of the recovery in the lymph depends on the chain length of the fatty acid; the shorter the chain length the less appears in the lymph (reviewed by Bergström and Borgström, 1955). Although long-chain fatty acids are mainly transported by the lymphatic route, it seems likely that a small amount does pass into the portal vein in the normal animal. For in the control rats given [U-14 ${ }^{14}$ ] oleic acid (80.0 mg.) only $82.0 \%$ of the ${ }^{14} \mathrm{C}$ absorbed was recovered in lymph lipids, and this incomplete recovery in lymph of absorbed longchain fatty acid is supported by other workers (Bloom et al., 1950; Chaikoff, Bloom, Stevens, Reinhardt, and Dauben, 1951; Borgström, 1952b; Bergström et al., 1954). In addition, after giving [U $\left.-{ }^{14} \mathrm{C}\right]$ oleic acid to a control group of rats with- out thoracic duct or bile fistulae, four of the five had slightly higher concentrations of radioactivity in portal than peripheral blood, and this has been observed by Kiyasu, Bloom, and Chaikoff (1952); however, as the blood samples were taken from anaesthetized animals one must be cautious in interpreting the results due to the profound effect of anaesthesia on fat absorption (Bergström et al., 1954). The proportion of absorbed long-chain fatty acid that is transported in the portal vein may represent that fatty acid in solution in the intestinal lumen. This would explain why significantly less of the $8.0 \mathrm{mg}$. than the $80.0 \mathrm{mg}$. of oleic acid was recovered in the lymph of control rats, for presumably a greater proportion of the small dose would be soluble and hence transported in the portal vein. In the bile fistula animal it is probable that longchain fatty acids are absorbed from a solution in the gut lumen, and are then transported as the free acid in the portal blood, a route which is used in the normal animal, but to a minor degree.

\section{SUMMARY}

A technique is described for collecting thoracic duct lymph in a portable glass saddle from an unrestrained rat. Uniformly labelled $\left[{ }^{14} \mathrm{C}\right]$ oleic acid in various physical states was given to rats with thoracic duct and bile fistulae to study the influence of bile salts on the amount absorbed and on the route of transport and esterification after absorption.

In the bile fistula rat only $7 \cdot 2 \%$ of the $\left[\mathrm{U}^{14} \mathrm{C}\right.$ ] oleic acid absorbed was recovered in the lymph and $28.0 \%$ of the lymph lipid radioactivity was free fatty acid. The recovery of absorbed fatty acid in lymph lipids was increased by emulsifying the $\left[\mathrm{U}-{ }^{14} \mathrm{C}\right]$ oleic acid given. However, only taurocholate and not Tween 20 or sonicated emulsions altered the proportion of lymph free fatty acid towards normal.

It is suggested that in addition to their emulsifying action, bile salts may stimulate the esterification of absorbed oleic acid by the intestinal mucosa.

We thank Miss Joan Webb and Dr. H. S. Wiggins for much help.

\section{REFERENCES}

Baker, R. D., and Searle, G. W. (1960). Bile salt absorption at various levels of rat small intestine. Proc. Soc. exp. Biol. (N.Y.), 105, $521-523$.

Barrnett, R. J., and Ball, E. G. (1959). Morphologic and metabolic changes produced in rat adipose tissue in vitro by insulin. Science, 129, 1282.

Bergström, S., Blomstrand, R., and Borgström, B. (1954). Route of absorption and distribution of oleic acid and triolein in the rat. Biochem. J., 58, 600-604.

- and Borgström, B. (1955). Some aspects of the intestinal absorption of fats. In Progress in the Chemistry of Fats anl other Lipids, vol. 3, edited by R. T. Holman, W. O. Lundberg, and T. Malkin. Pergamon Press, Oxford. 
Blomstrand, R. and Dahlbäck, O. (1960). The fatty acid composition of human thoracic duct lymph lipids. J. clin. Invest., 39, 1185-1191.

Bloom, B., Chaikoff, I. L., Reinhardt, W. O., Entenman, C., and Dauben, W. G. (1950). The quantitative significance of the lymphatic pathway in transport of absorbed fatty acids. J. biol. Chem., 184, 1-8.

Bollman, J. L., Cain, J. C., and Grindlay, J. H. (1948). Techniques for the collection of lymph from the liver, small intestine, or thoracic duct of the rat. J. Lab. clin. Med., 33, 1349-1352.

Borgström, B. (1952a). Investigation on lipid separation methods. Separation of cholesterol esters, glycerides, and free fatty acids. Acta physiol. scand., 25, 111-119.

- (1952b). On the mechanism of the intestinal fat absorption. IV. Metabolism of lipids 6. Ibid., 25, 291-314.

- (1953). On the mechanism of the intestinal fat absorption. V. The effect of bile diversion on fat absorption in the rat. Ibid., 28, 279-286.

- (1955). Transport form of ${ }^{14} \mathrm{C}$-decanoic acid in portal and inferior vena cava blood during absorption in the rat. Ibid., 34, 71-74.

- Dahlqvist, A., Lundh, G., and Sjövall, J. (1957). Studies of intestinal digestion and absorption in the human. $J$. clin. Invest., 36, 1521-1536.

- and Tryding, N. (1956). Free fatty acid content of rat thoracic duct lymph during fat absorption. Acta physiol. scand., 37, 127-133.

Chaikoff, I. L., Bloom, B., Stevens, B. P., Reinhardt, W. O., and Dauben, W. G. (1951). Pentadecanoic acid-5-C ${ }^{14}$ : its absorption and lymphatic transport. J. biol. Chem., 190, 431-435.

Dawson, A. M., and Isselbacher, K. J. (1960). Studies on lipid metabolism in the small intestine with observations on the role of bile salts. J. clin. Invest., 39, 730-740.

Folch, J., Lees, M., and Sloane Stanley, G. H. (1957). A simple method for the isolation and purification of total lipids from animal tissues. J. biol. Chem., 226, 497-509.

Frazer, A. C. (1943). Differentiation in the absorption of olive oil and oleic acid in the rat. J. Physiol. (Lond.), 102, 306-312.
Haslewood, G. A. D. (1955). Recent developments in our knowledge of bile salts. Physiol. Rev., 35, 178-196.

Hübscher, G., Clark, B., and Webb, M. E. (1962). Structural and enzymic aspects of fat metabolism in the small-intestinal mucosa. Biochem. J., 84, 23P.

Hughes, R. H., and Wimmer, E. J. (1935). The absorption of soluble, volatile fatty acids. J. biol. Chem., 108, 141-144.

Kiyasu, J. Y., Bloom, B., and Chaikoff, I. L. (1952). The portal transport of absorbed fatty acids. Ibid., 199, 415-419.

Mainland, D. (1952). Elementary Medical Statistics, p. 282. Saunders, Philadelphia and London.

Mangold, H. K., and Malins, D. C. (1960). Fractionation of fats, oils and waxes on thin layers of silicic acid. J. Amer. Oil chem. Soc. 37, 383-385.

Munk, I. (1890). Uber die Resorption von Fetten und festen Fettsäuren nach Ausschluss der Galle vom Darmkanel. Virchows Arch. path. Anat., 122, 302-325.

Norman, A. (1955). Preparation of conjugated bile acids with mixed carboxylic acid anhydrides. Ark. Kemi., 8, 331-342.

Olson, J. A. (1961). The conversion of radioactive $\beta$-carotene into vitamin $A$ by the rat intestine in vivo. J. biol. Chem., 236, 349-356.

Palay, S. L., and Karlin, L. J. (1959). An electron microscopic study of the intestinal villus. II. The pathway of fat absorption. J. biophys. biochem. Cytol., 5, 373-384.

Pessoa, V. C., Kim, K. S., and Ivy, A. C. (1953). Fat absorption in absence of bile and pancreatic juice. Amer. J. Physiol., 174, 209-218.

Senior, J. R., and Isselbacher, K. J. (1961). Formation of higher glycerides from monopalmitin and palmityl-CoA by microsomes of rat intestinal mucosa. Biochem. biophys. Res. Commuin., 6, 274-278.

Vahouny, G. V., Woo, C. H., and Treadwell, C. R. (1958). Quantitative effects of bile salt and fatty acid on cholesterol absorption in the rat. Amer. J. Physiol., 193, 41-46.

Van Zyl, A. (1957). Note on the effects of thyroidectomy and thyroid hormone administration on the concentration of bile cholesterol and cholic acid. J. Endocrin., 16, 213-216.

Weiner, I. M., and Lack, L. (1962). Absorption of bile salts from the small intestine in vivo. Amer. J. Physiol., 202, 155-127. 